\title{
Pelaksanaan Pembelajaran Pendidikan Agama Islam Bagi Anak Berkebutuhan Khusus Tunagrahita di Masa Pandemi Covid-19
}

\author{
Datul Ishmi \\ Program Pascasarjana Universitas Muhammadiyah Sumatera Barat \\ Email: datulishmi@gmail.com
}

\begin{abstract}
This study aims to find out the implementation of PAI learning in two extraordinary schools, namely SLB Koto Agung and SLB Negeri 1 Pulau Punjung. This type of research is qualitative research, the source of research data is pai teachers in both SLB research places, and learners, data analysis techniques used are comparisons. And the learning methods applied were methods.ceramah, demonstrasi,.tanya answer, drill, repetition, and assignment. There are similarities in the implementation of PAI learning in both SLB, namely the type of curriculum used, while the differences in general are in the implementation of learning during the pandemic. Meanwhile, SLB N 1 Pulau Punjung in the implementation of PAI learning during the pandemic visited in turn, and the support from parents was less so providing support as well as in SLB Koto Agung.
\end{abstract}

Keywords: pai learning, tunagrahita, Covid-19

\begin{abstract}
Abstrak
Penelitian ini bertujuan untuk mengetahui pelaksanaan pembelajaran PAI pada dua sekolah luar biasa yakni SLB Koto Agung dan SLB Negeri 1 Pulau Punjung. Jenis penelitian adalah penelitian kualitatif, sumber data penelitian adalah guru PAI di kedua SLB tempat penelitian, dan peserta didik, teknik analisis data yang digunakan ialah komparasi. Dan metode pembelajaran yang diterapkan adalah metode ceramah, demonstrasi, tanya jawab, drill, pengulangan, dan penugasan. Terdapat persamaan pelaksanaan pembelajaran PAI di kedua SLB ini yakni jenis kurikulum yang digunakan, sementara perbedaan secara umum terdapat pada pelaksanaan pembelajaran di masa pandemic. Sedangkan SLB N 1 Pulau Punjung dalam pelaksanaan pembelajaran PAI dimasa pandemic melakukan visiting secara bergilir, dan dukungan dari orang tua kurang begitu memberikan dukungan sebaik di SLB Koto Agung.
\end{abstract}

Kata Kunci: Pembelajaran PAI, tunagrahita, Covid-19 


\section{Pendahuluan}

Undang-undang Negara republik Indonesia menjamin bahwa pendidikan itu adalah hak seluruh warga Negara, dalam hal ini terdapat makna bahwa hak untuk mendapatkan pendidikan bagi warga Negara tanpa dibedakan suku, ras, agama, warna kulit apalagi kondisi fisik. Implementasi dari undang-undang tersebut Negara kemudian menyediakan sekolah luar biasa untuk memfasilisitasi warga Negara yang membutuhkan pelayanan khusus dalam bidang pendidikan ${ }^{1}$

Penyamaan hak pemberian pendidikan yang sama bagi peserta didik normal dan peserta didik tunagrahita ${ }^{2}$, akan dapat meminimalisir kesenjangan angka partisipasi pendidikan bagi peserta didik tunagrahita. Peserta didik berkebutuhan khusus tunagrahita mempunyai karakteristik yang berbeda antara peserta didik satu dengan peserta didik yang lainnya. ${ }^{3}$ Peserta didik ini mempunyai gangguan perkembangan dan khusus dalam pemberian pelayanannya baik perawatannya ataupun pembelajarannya harus menerapkan strategi dan metode yang bervariatif dengan menyesuaikan kondisi peserta didik. $^{4}$

Menilik terhadap perbedaan kelebihan dan kekurangan peserta didik, pendidik harus mampu mendidik dan mengarahkan kelebihan dan kekurangan peserta didik tersebut menjadi kelebihan ${ }^{5}$. Dan kekurangannya dapat mejadi sebuah kompetensi yang dapat menjadikan peserta didik mengontrol kekurangannya dan menjadikan kelebihannya sebagai nilai plus untuk kehidupannya dimasa yang akan dating, sehingga perkembangan peserta didik dapat dioptimalkan khususnya bagi peserta didik tunagrahita. ${ }^{6}$

Ketersediaan lembaga pendidikan yang dibangun oleh pemerintah maupun swasta pada masa covid-19 ini seakan kurang berfungsi disebabkan keharusan untuk menjaga jarak, work from home, learning from home kegiatan

${ }^{1}$.Pramudiana, I. D. Implementasi Kebijakan Pendidikan Inklusif untuk ABK di Surabaya. Jurnal Dimensi Pendidikan Dan Pembelajaran. 2017. 5(1), h.1-9.

${ }^{2}$.Husna, dkk. Hak Mendapatkan Pendidikan Bagi Anak Berkebutuhan Khusus Dalam Dimensi Politik Hukum Pendidikan (The Right to Obtain Education for Children with Special Needs in the Political Dimensions of Educational Law). SALAM; Jurnal Sosial \& Budaya Syar-i FSH. 2019. 6(2), h. 207-228.

3. Widiastuti, dkk. Prinsip Khusus dan Jenis Layanan Pendidikan Bagi Anak Tunagrahita. Jurnal Santiaji Pendidikan. 2019. 9(2), h. 116-126.

4. Kumalasari, dkk. Metode Pembelajaran Pendidikan Agama Islam pada Anak Tunagrahita di SLB C Muzdalifah Medan. TAZKIR: Jurnal Penelitian Ilmu-Imu Sosial Dan Keislaman, 2019. 05(1), h.1-24.

${ }^{5}$ Ritonga, M.. Learning From Home (LFH) dan Kerinduan yang Mendalam. In Inovasi Pembelajaran Era Covid-19 Pengalaman \& Pengamatan Selama Pandemi Covid19 (pp. 80-83.2020). Cv Markumi.

${ }^{6}$ Alim, dkk. Korelasi Kegiatan Ekstrakurikuler Sanggar Al-Quran dengan Hasil Belajar AlQuran Hadits di MAN 4 Pasaman Barat. Intiqa: Jurnal Agama Dan Pendidikan Islam, 2020. 12(2), h. 246-255. 
PSBB dan lembaga-lembaga pendidikan ditutup. ${ }^{7}$ Akibat dari kondisi covid-19 sistem pembelajaran beralih dari yang biasanya berlangsung di ruang kelas ke ruang online dengan memanfaatkan berbagai platform yang tersedia. ${ }^{8}$

Pembelajaran secara online di masa covid-19 sebagaimana diungkapkan oleh Sartika dan kawan-kawan bahwa mendapatkan berbagai problem seperti peserta didik yang tidak bisa mengikuti secara full proses pembelajaran, guru yang belum terbiasa untuk memanfaatkan berbagai media yang bersifat online. ${ }^{9}$ Giatman juga mengingatkan bahwa karena pembelajaran secara online membutuhkan biaya maka tidak sedikit di antara peserta didik yang merasa kesulitan untuk membiayai pembelajaran di masa pandemic covid-19. ${ }^{10}$

Pembelajaran sebagai kegiatan transfer ilmu dalam situasi normal sendiri dihadapkan terhadap permasalahan seperti sulitnya daya tangkap bagi peserta didik, ${ }^{11}$ hal itu bisa saja terjadi bagi peserta didik yang kondisi fisiknya normal. Dapat dibayangkan bahwa realita yang demikian akan semakin terlihat pada peserta didik yang disebut dengan anak berkebutuhan khusus. ${ }^{12}$

Sementara itu, pembelajaran pendidikan agama Islam bagi seluruh peserta didik dan semua jenjang pendidikan di Indonesia merupakan hak bagi seluruh siswa dan diajarkan oleh guru yang beragama Islam, ${ }^{13}$ dan hal ini diatur dalam undang-undang pendidikan nasional. ${ }^{14}$ Pandangan ini menunjukkan bahwa dalam kondisi apapun baik situasi normal maupun kondisi pandemic pendidikan agama Islam sebagai bagian dari kurikulum pendidikan nasional, ${ }^{15}$ mesti diajarkan sebagaimana mata pelajaran lainnya.

${ }^{7}$ Ritonga, dkk. Curriculum Development Strategy Management for Student Mental Health in Covid-19 Pandemic. International Journal of Pharmaceutical Research, 2020. 12(Spessial Issu 2.), h. 4489-4494.

${ }^{8}$ Suparman, dkk. (2020). The Implementation of Community Partnership Program to Improve the Quality of Online Learning during the Covid-19 Pandemic. Universal Journal of Educational Research, 8. 2020. (11B),h. 6134-6138.

${ }^{9}$ Sartika, dkk. Implementation of Islamic Religious Education in Madrasah Ibtidaiyah During Covid-19 Pandemic. Khalifa: Journal of Islamic Education, 2020. 4(2), h. 97-117.

${ }_{10}$ Giatman, dkk. Online Learning Quality Control in the Pandemic Covid-19 Era in Indonesia. Journal of Nonformal Education, 2020. 6(2), h. 168-175.

${ }_{11}$ Munirah. Peranan Guru dalam Mengatasi Kesulitan Belajar Siswa. TARBAWI: Jurnal Pendidikan Agama Islam, 2018. 3(2), h. 111-127.

${ }^{12}$ Inayah, R., \& Rahayu, S. Exploring Students' Diffulties in Comprehending Reading for Academic Materials Used Their Class. Jurnal Ilmiah UPT P2M STKIP Siliwangi, 2015. 2(2), h. $240-245$.

13 Nusyirwan. Kontestasi pendidikan keislaman dan pendidikan umum: persepsi masyarakat tentang sumber kekuatan mobilitas sosial di kabupaten bone. EKSPOSE: Jurnal Penelitian Hukum Dan Pendidikan, 2020. 19(1), 928-938.

${ }^{14}$ Hotmaida, dkk. Pembelajaran Pendidikan Agama Islam di Sekolah Dasar: Analisis terhadap Kompetensi Guru, Strategi dan Kualitas Hasil. Ruhama: Islamic Education Journal, 2020. 3(2), h. 29-42.

15 Zulfa, U. Model of Islamic Religion Education 435 Based on Islam Nusantara on College. Nadwa : Jurnal Pendidikan Islam, 2018. 12(51), h. 1-14. 
Anak-anak dengan kebutuhan khusus seperti yang dijelaskan di atas maka diperlukan strategi pembelajaran yang tepat sesuai dengan kekhususan yang dimiliki anak-anak tersebut. Berdasarkan observasi awal penulis di dua sekolah luar biasa yaitu di SLB Koto Agung Kec. Sitiung dan SLB Negeri 1 Pulau Punjung yang berada di Kab. Dharmasraya. Penulis melihat guru di kedua sekolah tersebut melakukan strategi tertentu dalam menguasai kelas dan pembelajaran yang diberikan kepada anak-anak berkebutuhan khusus dalam hal ini anak-anak tunagrahita, dan melaksanakan proses pembelajaran dan memanfaatkan sarana dan prasarana yang ada dalam proses pembelajaran.

Berdasarkan pemaparan tentang kondisi pembelajaran di masa covid-19, posisi pentingnya pembelajaran Pendidikan Agama Islam serta pembelajaran untuk anak berkebutuhan khusus sebagaimana yang dijelaskan di atas, peneliti tertarik untuk mengkaji lebih dalam bagaimana pembelajaran Pendidikan Agama Islam untuk anak Tunagrahita pada dua SLB yakni SLB Koto Agung dan SLB Negeri 1 Pulau Punjung.

\section{Metodologi Penelitian}

Lokasi penelitian ini ialah di dua sekolah luar biasa yang ada di Kabupaten Dharmasraya, yakni SLB Koto Agung dan SLB Negeri 1 Pulau Punjung, kedua SLB ini dipilih sebagai lokasi penelitian ialah dikarenakan tujuan penelitian yang ingin membandingkan proses pembelajaran PAI pada kedua sekolah dan status keduanya berbeda, yakni 1 sekolah merpakan swasta dan 1 sekolah lagi merupakan Negeri.

Pelaksanaan penelitian sejak Maret 2020 awal menyebarnya virus corona di Indonesia khususnya dilakukan observasi awal, kemudian disusun proposal penelitian yang diarahkan oleh dua orang dosen pembimbing yang kemudian dilanjutkan tahap seminar proposal, dan setelah memperbaiki hasil seminar proposal mendapatkan izin penelitian yang kemudian dilanjutkan penelitian sejak Mei-November 2020, dan pada bulan Desember 2020 hasil penelitian dapat dipertahankan di hadapan para penguji tesis Program Pascasarjana Universitas Muhammadiyah Sumatera Barat.

Sumber penelitian ini ialah guru yang mengajar PAI pada kedua sekolah luar biasa beserta beberapa orang peserta didik yang dipilih secara purvosif. Teknik ini dipilih karena kondisi covid-19 yang tidak memungkinkan bagi peneliti untuk menentukan jumlah peserta didik yang akan dijadikan sebagai sumber informasi.

Data dikumpulkan dari guru PAI dan peserta didik melalui observasi dan wawancara, maksudnya di sini ialah bahwa peneliti mengamati secara langsung kegiatan guru dan peserta didik yang terkait dengan pembelajaran PAI selama covid-19. Peneliti tidak hanya mengamati apa yang mereka lakukan, melainkan diperkuat dengan wawancara untuk mendapatkan kejelasan maksud dan tujuan apa yang dilakukan informan pada saat pembelajaran PAI di masa covid-19. Semua data yang didapatkan kemudian dianalisis secara kualitatif dengan pendekatan komparatif, yakni peneliti melakukan analisis perbandingan tentang 
pembelajaran PAI bagi anak tunagrahita pada kedua sekolah untuk mendapatkan kejelasan tentang aspek perbedaan dan persamaan khsususnya selama covid-19.

\section{Hasil dan Pembahasan}

Sekolah luar biasa Koto Agung Kecamatan Sitiung memiliki peserta didik sebanyak 32 (tiga puluh dua) yang terdiri dari beberapa jenis kebutuhan khususnya seperti tunarungu, tunadaksa, autis, tunagrahita ringan, dan tunagrahita sedang, jumlah 32 tersebut juga tersebar pada berbagai kelas dan jenjang sekolah mulai dari Sekolah Dasar, sekolah lanjutan tingkat pertama sampai pada sekolah lanjutan tingkat atas, data tersebut dapat dilihat sebagaimana pada table 1 di bawah ini:

Tabel 1. Jumlah Peserta Didik Pertunaan di SLB Koto Agung

\begin{tabular}{|c|c|c|c|c|c|c|c|c|c|}
\hline No & Jenis Tuna & Jenjang & & & & & & & Jumlal \\
\hline & & SD & 1 & 2 & 3 & 4 & 5 & 6 & \\
\hline 1 & Tunarungu & & & 1 & & 1 & & & 2 \\
\hline 2 & Tunadaksa & & & & & & 1 & 1 & 2 \\
\hline 3 & Autis & & & & 3 & & 2 & & 5 \\
\hline 4 & Tunagrahita Ringan & & 1 & 2 & & 2 & 4 & & 9 \\
\hline 5 & Tunagrahita Sedang & & & & & & 1 & 3 & 4 \\
\hline & & SLTP & 7 & 8 & 9 & & & & \\
\hline 1 & Tunarungu & & 1 & & & & & & 1 \\
\hline 2 & Tuna grahita Ringan & & 3 & 1 & 2 & & & & 6 \\
\hline 3 & Tunagrahita sedang & & & 1 & & & & & 1 \\
\hline 4 & Tunadaksa & & 1 & & & & & & 1 \\
\hline & & SLTA & 10 & 11 & 12 & & & & \\
\hline 1 & Tunagrahita ringan & & 1 & & & & & & 1 \\
\hline
\end{tabular}

Dari data tabel 1 di atas dapat diketahui bahwa SLB Koto Agung Kec. Sitiung membuka layanan semua tingkat ketunaan dan membuka tingkat rombongan belajar dari SD sampai dengan SMA, dari tabel di atas jumlah tingkat SD sebanyak 23 peserta didik dengan kategori tuna rungu sebanyak 2 peserta didik, tuna daksa 2 peserta didik, autis 5 peserta didik, tunagrahita ringan 9 peserta didik dan tunagrahita sedang sebanyak 2 peserta didik. Pada tingkat SDLB terdapat 6 rombongan belajar dengan spesifikasi kelas I berjumlah satu orang peserta didik, kelas II berjumlah 3 orang peserta didik, kelas III berjumlah 4 orang peserta didik, kelas IV berjumlah 3 orang peserta didik, kelas V berjumlah 6 orang peserta didik dan kelas VI berjumlah 9 peserta didik.

Dari hasil wawancara diperoleh data bahwa semua kegiatan pembelajaran harus direncanakan, di program terlebih dahulu sehingga proses pembelajaran berlangsung dengan baik dan lancar sesuai yang diharapkan. Adapun kurikulum PAI yang diterapkan di SLB N 1 Pulau Punjung adalah kurikulum 2013 yang sama dengan yang diterapkan di sekolah pada umumnya, namun di SLB N 1 Pulau Punjung kebutuhannya dicocokkan dengan keadaan siswa penyandang tunagrahita.

Kegiatan belajar mengajar haruslah diprogram dan direncanakan sebelum seorang pendidik mulai melaksanakan dan memberikan pembelajaran 
kepada peserta didiknya, ${ }^{16}$ hal ini bertujuan agar target pembelajaran sesuai dengan pedoman kurikulum dan silabus yang digunakan. ${ }^{17}$ Oleh sebab itu, kepala sekolah sebagai supervisor harus mengerti dan paham dengan tugasnya untuk melakukan supervisi terhadap guru dan stafnya. ${ }^{18}$ Menjadi seorang kepala sekolah bukanlah hal mudah dan sepele, karena kepala sekolah harus mempunyai pemahaman dan wawasan yang luas sebagai kreator, sebagai inspirator dan supervisor yang membuat ide-ide kreatif dalam memfasilitasi pelaksanaan pendidikan dan pembelajaran yang akan dilaksanakan guru di sekolah.

Dalam pratek belajar mengajar PAI di SLB N 1 Pulau Punjung guru menerapkan strategi belajar yang bersifat kelompok dan individual sebagai metode refleksi dari pembelajaran yang bersifat kelompok dengan menggunakan pendekatan pembiasaan, pengalaman, emosional dan keteladanandisesuaikan dengan karakter peserta didiknya. Agar materi yang diajarkan mudah dicerna oleh peserta didik. Sehingga dapat meningkatkan potensi peserta didik. Sebab prinsip pembelajaran di SLB N Pulau Punjung khususnya peserta didik tunagrahita itu bukan untuk mencaPAI semua tujuan yang telah ditetapkan, akan tetapi lebih kepada menekankan pada proses penggalian potensi untuk mengetahui batas maksimal potensi yang dimiliki peserta didik tunagrahita.

Beberapa pendekatan diterapkan oleh guru PAI di SLB N 1 Pulau Punjung, diantaranya pendekatan pembiasaan, pendekatan ini terlihat pada saat setiap memulai dan mengakhiri pembelajaran, pengajar menyampaikan salam, mengajak peserta didik untuk berdoa melafalkan surat al-Fatihah dan menghafal surat-surat pendek. Selain itu kepala sekolah dan guru PAI menyarankan kepada wali peserta didik untuk membiasakan shlat berjamaah walaupun di rumah minimal shalat secara individu secara terbimbing, kemudian membiasakan peserta didik untuk menulis, menebalkan tulisan dan membaca pelajaran yang diajarkan.

Pendekatan pengalaman, dalam pendekatan pengalaman ini guru memberikan materi keagamaan seperti tata cara wudhu, tata cara shalat, menulis huruf hijaiyah, menunjukkan mana perbuatan baik maupun perbuatan buruk serta memberikan penguatan apabila tidak melaksanakan shalatakan berdosa dan masuk neraka. Kemudian guru menunjukkan gambar-gambar yang bernuansa Islam seperti gambar orang berdoa dan lain sebagainya.

${ }^{16}$ Roza, A., \& Rifma. (2020). Perencanaan pembelajaran anak berkebutuhan khusus dalam majamen sekolah inklusif. (JKPD) Jurnal Kajian Pendidikan Dasar, 2020. 5(1), h. 61-69.

${ }^{17}$ Ritonga, dkk. Curriculum Development Strategy Management for Student Mental Health in Covid-19 Pandemic. International Journal of Pharmaceutical Research, 2020. 12(Spessial Issu 2), h. 4489-4494.

18 Husna, dkk. The Teachers Unpreparedness in Carrying Out Islamic Education Learning using the Revised 2013 Curriculum in Elementary School. European Journal of Molecular \& Clinical Medicine, 2020. 7(2), h. 1520-1528. 
Sedangkan pendekatan keteladanan, guru memberikan contoh gerakan shalat, gerakan wudhu, peserta didik disuruh untuk mengikuti dan menirukan apa yang diperagakan guru. ${ }^{19}$ Begitu juga dalam menghafalkan surat-surat pendek guru juga membaca dan peserta didik menirukan, mengajari untuk saling meminta maaf, dan menunjukkan perbuatan baik dan perbuatan buruk. Kegiatan ini dilakukan secara berulang-ulang. ${ }^{20}$

Pada pendekatan emosional guru memberikan penguatan terhadap peserta didik, agar dapat menstimulus emosionalnya sampai timbul keinginan melaksanakan apa yang dianjurkan di dalam agama Islam. ${ }^{21}$ Misalkan memotivasi untuk tertib dalam shalat, apabila meninggalkannya akan berdosa, menumbuhkan semangat dalam berbagai aktivitas khususnya dalam mengikuti pembelajaran. ${ }^{22}$ Sehingga pendekatan pembelajaran Pendidikan Agama Islam diatas saling berkaitan.

\section{Gambar. 3 Flowcharts Pendekatan PAI}

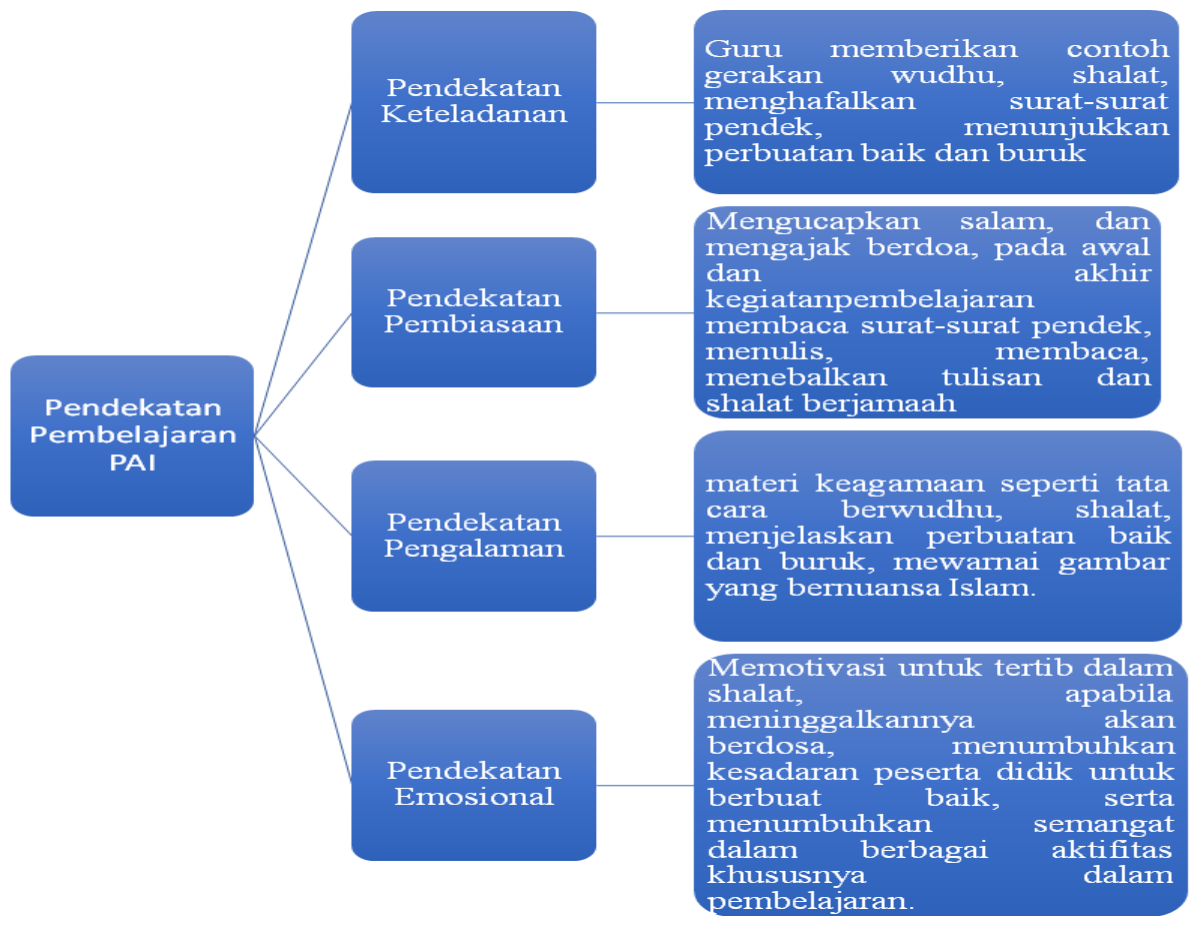

19 Wati, dkk. Peran Guru Pada Siswa Disabilitas di Sekolah Luar Biasa Kota Surabaya. BioKultur, 2018. VII(1), h.72-87.

${ }^{20}$ Alfiyah, dkk. Evaluasi Pengenalan Tata Cara Berwudhu dalam Pengembangan Pendidikan Agama Islam Melalui Media Gambar pada Kelompok B di RA Asiah Kota Pekanbaru. GENERASI EMAS: Jurnal Pendidikan Anak Usia Dini, 2019. 2(1), h.73-83.

${ }^{21}$ Nur, dkk. Pengamalan ajaran agama islam dalam kehidupan bermasyarakat. Jurnal AlMauzhah, 2018. 1(1), h. 1-11.

${ }^{22}$ Hanisy, A. Pengaruh Pendidikan Agama Islam terhadap Motivasi Sholat Berjamaah di MA Al-Qodiri Jember Tahun Pelajaran 2015/2016. AL-QODIRI: Jurnal Pendidikan Sosial Dan Keagamaan, 2016. 10(1), h. 53-67. 
Dari pembahasan pelaksanaan belajar mengajar PAI terhadap peserta didik penyandang tunagrahita di SLB Koto Agung dan SLB N 1 Pulau Punjung diatas terdapat beberapa persamaan dan perbedaan dalam pelaksanaan pembelajaran PAI bagi peserta didik berkebutuhan khusus tunagrahita terutama pada masa pandemic covid-19 yang terjadi saat ini, di bawah ini adalah persamaan dan perbedaan yang di dapatkan di SLB Koto Agung dan SLB N 1 Pulau Punjung, kedua aspek yang dimaksud dapat digambarkan sebagaimana pada tabel 2.

Tabel 2. Aspek Perbedaan dan Persamaan Pembelajaran PAI di Sekolah Luar

\section{PERBEDAAN}

Biasa pada masa Covid-19

\section{PERSAMAAN}

\section{SLB Koto Agung \\ Guru bukan dari
lulusan program \\ studi PAI}

Guru PLB

\section{SLB N I Pulau Punjung}

Guru PAI

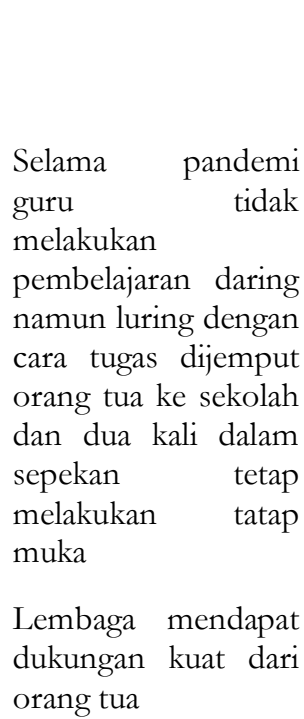

Bukan Guru PLB

Selama pandemic guru melakukan visiting ke rumah peserta didik secara bergilir dan peserta didik belajar di rumah tidak melakukan tatap muka di sekolah

Kurang mendapat
apresiasi kuat dari
orang tua dan
masyarakat

Melakukan

Perencanaan

Pembelajaran

Menerapkan Metode Pembelajaran, (metode ceramah, demonstrasi, tanya

\section{SLB N I Pulau} Punjung
Menggunakan

Kurikulum PAI 2013

yang disesuaikan dengan kebutuhan anak tunagrahita

$\begin{array}{lr}\text { Menerapkan } & \text { Strategi } \\ \text { Belajar } & \text { secara } \\ \text { kelompok } & \text { dan } \\ \text { Individu } & \end{array}$

Menggunakan Alat/ Media Pembelajaran
Menggunakan

Kurikulum PAI 2013

yang disesuaikan dengan kebutuhan anak tunagrahita

Menerapkan Strategi Belajar secara kelompok dan Individu

Menggunakan Alat/ Media Pembelajaran

\section{Melakukan \\ Perencanaan \\ Pembelajaran}

Menerapkan Metode Pembelajaran, (metode ceramah, demonstrasi, 


$\begin{array}{ll}\text { jawab, tugas, drill } & \text { tanya jawab, tugas, drill } \\ \begin{array}{l}\text { Melakukan refleksi } \\ \text { setelah pembelajaran }\end{array} & \begin{array}{l}\text { Melakukan refleksi } \\ \text { setelah pembelajaran }\end{array} \\ \text { melakukan evaluasi } & \text { melakukan tes hasil } \\ \begin{array}{l}\text { pembelajaran, baik } \\ \text { ulangan harian, UTS hajar, baik ulangan }\end{array} & \text { harian, UTS juga UTS } \\ \text { serta UAS } & \end{array}$

Kegiatan pembelajaran tidak hanya bertumpu pada salah satu metode saja, metode tersebut juga harus dicocokkan dengan bahan ajar yang akan disampaikan dan diajarkan. Untuk itu di SLB N 1 Pulau Punjung dalam pelaksanaan pembelajaran PAI menggunakan beberapa metode pembelajaran.

Berikut ini adalah beberapa strategi belajar mengajar PAI yang diterapkan oleh guru PAI di SLB N 1 Pulau Punjung selama covid-19, pertama Metode Ceramah digunakan untuk menjelaskan semua materi seperti pengertian wudhu, shalat, pengertian perbuatan baik dan perbuatan buruk, adab makan dan lain sebagainya. Metode ceramah dalam pembelajaran adalah suatu metode yang telah lama digunakan, ${ }^{23}$ dan menurut analisis peneliti metode ini kurang tepat digunakan untuk pembelajaran PAI bagi peserta didik tunagrahita ditambah lagi suasana covid-19. ${ }^{24}$

Kedua, Metode Tanya Jawab digunakan untuk mengetahui sejauhmana daya serap peserta didik pasca dilaksanakannya aktivitas proses belajar mengajar, dan untuk mengingat materi yang sudah diajarkan. Dalam kondisi covid-19 metode ini terlihat kurang pas digunakan apalagi kondisi peserta didiknya tunagrahita, pandangan ini didasarkan pada sifat metode ceramah ini yang lebih tepat untuk peserta didik dengan kondisi fisik normal. ${ }^{25}$

Metode Demonstrasi diterapkan untuk mendemokan atau memperagakan praktek gerak-gerakan wudhu, shalat, ${ }^{26}$ mewarnai, dan menebalkan tulisan peserta didik. ${ }^{27}$ Metode Drill diterapkan untuk melatih peserta didik terampil dan manndiri seperti peserta didik dilatih menulis,

${ }^{23}$ Tambak, S. (2014). Metode Ceramah: Konsep dan Aplikasinya dalam Pembelajaran Pendidikan Agama Islam. Jurnal Tarbiyah, 21(2).h.456-468

${ }^{24}$ Santoso, dkk. Evaluasi Pelaksanaan Pembelajaran Online di Tengah Pandemi Covid-19. In D. H. Santoso \& A. Santosa (Eds.), Covid-19 dalam Ragam Tinjauan Perspektif (pp. 69-80). MBridge Press 2020.

${ }^{25}$ Sitohang, J. Penerapan Metode Tanya Jawab untuk Meningkatkan Hasil Belajar IPA pada Siswa Kelas Dasar. Suara Guru: Jurnal Imu Pendidikan Sosial, Sains, Dan Humaniora Vol. 2017. 3(4), h. 681-688.

26 Hakim, dkk. A Study of Religion Education Method With Multicultural Insight. International Seminar on Islamic Education (ISIE 2018) Faculty of Islamic Religion, Universitas Muhammadiyah Ponorogo, July 07th, 2018, Isie 2018, h. 81-97.

27 Moreira, dkk. Effectiveness of the Implementation the Demonstration Method to Increase the Result of Physic Study on Electric Resistance. ISCE Journal of Innovative Studies on Character and Education, 2017. 1(1), h. 104-118. 
menebalkan tulisan dan lain sebagainya. Metode Penugasan dan Resitasi diterapkan untuk supaya peserta didik mengerjakan apa yang diperintahkan oleh guru terkait dengan materi pembelajaran sampai aktivitas belajar mengajar inimenjadi pengalaman dan berkesan bagi peserta didik. Metode Pengulangan diterapkan karena menimbang kondisi peserta didik tunagrahita yang memiliki keterbatasan intelegensi di bawah rata, sehingga materi memerlukan pengulangan yang terus menerus, jadi apapun materi yang disampaikan dan diajarkan harus di ulang-ulang apabila tidak maka materi yang diajarkan akan mudah dilupakan dan hilang.

\section{Penutup}

Setelah pengamatan kemudian hasil peneitian didapatkan di lapangan selanjutnya peneliti menganalisisa semua data, sehingga kesimpulan yang peneliti dapatkan adalah sebagai berikut: pertama, Pelaksanaan Belajar Mengajar pada materi PAI yang dilakukan terhadap peserta didik penyandang tunagrahita di SLB Koto Agung dan SLB Negeri 1 Pulau Punjung sangat bagus dalam proses pembelajaran yang menggunakan metode pembelajaran yaitu motede ceramah, metode demonstrasi dan juga dengan menggunakan metode cerita. Kedua, Selain itu faktor keberhasilan dalam pembelajaran bagi anak berkebutuhan khusus tunagrahita adalah kesinergian antara pihak sekolah, guru dan orang tua peserta didik, pada poin ini SLB Koto Agung lebih mendapat apresiasi, respon serta dukungan baik dari para orang tua seangkan SLB N 1 Pulau Punjung orang tua peserta didik kurang memperdulikan perkembangan anak di sekolah.

\section{Referensi}

Akmal, R., \& Ritonga, M. (2020). Learning of Islamic Religious Education in Covid-19 Period: Analysis of Problems and Solutions for Parents. TARBAWI: Jurnal Pendidikan Agama Islam, 05(02).

Alam, L. (2020). Islamic Education Policy Contestation in the Era of The New Order and the Reformation Kontestasi Kebijakan Pendidikan Islam di Era Orde Baru dan Reformasi. Ruhama: Islamic Education Journal, 3(2). https://doi.org/10.31869/ruhama.v3i2.2223

Alfiyah, Pratama, M. M., Nurhasanah, R., \& Wahyuni, I. W. (2019). Evaluasi Pengenalan Tata Cara Berwudhu dalam Pengembangan Pendidikan Agama Islam Melalui Media Gambar pada Kelompok B di RA Asiah Kota Pekanbaru. GENERASI EMAS: Jurnal Pendidikan Anak Usia Dini, 2(1).

Alim, N., Ritonga, M., \& Mafardi. (2020). Korelasi Kegiatan Ekstrakurikuler Sanggar Al-Quran dengan Hasil Belajar Al-Quran Hadits di MAN 4 Pasaman Barat. Intiqa: Jurnal Agama Dan Pendidikan Islam, 12(2), 246-255. https://doi.org/10.30596/intiqad.v12i2.4640

Giatman, M., Siswati, S., \& Basri, I. Y. (2020). Online Learning Quality Control in the Pandemic Covid-19 Era in Indonesia. Journal of Nonformal Education, 6(2). https://doi.org/10.15294/jne.v6i2.25594

Hakim, R., \& Ritonga, M. (2018). A Study of Religion Education Method With Multicultural Insight. International Seminar on Islamic Education (ISIE 2018) 
Faculty of Islamic Religion, Universitas Mubammadiyah Ponorogo, July 07th, 2018, Isie 2018.

Hakim, R., Ritonga, M., Khadijah, \& Susanti, W. (2020). Implementation of Contextual Teaching and Learning in Islamic Education at Madrasah Diniyah. Journal of Advanced Research in Dynamical \& Control Systems, 12(02). https://doi.org/10.5373/JARDCS/V12I2/S20201455

Hanisy, A. (2016). Pengaruh Pendidikan Agama Islam terhadap Motivasi Sholat Berjamaah di MA Al-Qodiri Jember Tahun Pelajaran 2015/2016. ALQODIRI: Jurnal Pendidikan Sosial Dan Keagamaan, 10(1). https://doi.org/10.1234/al\%20qodiri.v10i1.1621

Hotmaida, Ritonga, M., \& Mursal. (2020). Pembelajaran Pendidikan Agama Islam di Sekolah Dasar: Analisis terhadap Kompetensi Guru, Strategi dan Kualitas Hasil. Rubama: Islamic Education Journal, 3(2). https://doi.org/https://doi.org/10.31869/ruhama.v3i2.2221

Husna, F., Yunus, N. R., \& Gunawan, A. (2019). Hak Mendapatkan Pendidikan Bagi Anak Berkebutuhan Khusus Dalam Dimensi Politik Hukum Pendidikan (The Right to Obtain Education for Children with Special Needs in the Political Dimensions of Educational Law). SALAM; Jurnal Sosial B Budaya Syar-i FSH, 6(2). https://doi.org/10.15408/sjsbs.v6i1.10454

Husna, S. A., Ritonga, M., Lahmi, A., Saputra, R., \& Ayu, S. (2020). The Teachers Unpreparedness in Carrying Out Islamic Education Learning using the Revised 2013 Curriculum in Elementary School. European Journal of Molecular \& Clinical Medicine, 7(2), 1520-1528.

Inayah, R., \& Rahayu, S. (2015). Exploring Students' Diffulties in Comprehending Reading for Academic Materials Used Their Class. Jurnal Ilmiah UPT P2M STKIP Siliwangi, 2(2).

Indrawati, T. (2016). Pelaksanaan pembelajaran anak tunagrahita. Jurnal Pendidikan Guru Sekolah Dasar, 14(5).

Iswari, N., Mursal, \& Rahmi. (2020). Praying in The Subject of Practice of Worship in SMK Muhammadiyah 1 Padang. Ruhama: Islamic Education Journal, 3(1).

Kumalasari, I., \& Sormin, D. (2019). Metode Pembelajaran Pendidikan Agama Islam pada Anak Tunagrahita di SLB C Muzdalifah Medan. TAZKIR: Jurnal Penelitian Ilmu-Ilmu Sosial Dan Keislaman, 05(1).

Mayya, Sa’ud, U. S., \& Meirawan, D. (2019). Analisis Implementasi Kebijakan Pendidikan Inklusi pada Sekolah Dasar. Jurnal Administrasi Pendidikan, 26(1).

Moreira, I. X., \& Filomeno, C. B. (2017). Effectiveness of the Implementation the Demonstration Method to Increase the Result of Physic Study on Electric Resistance. ISCE Journal of Innovative Studies on Character and Education, 1(1).

Munirah. (2018). Peranan Guru dalam Mengatasi Kesulitan Belajar Siswa. TARBAWI: Jurnal Pendidikan Agama Islam, 3(2). 
Nur, A. Z., \& Nuriati. (2018). Pengamalan ajaran agama islam dalam kehidupan bermasyarakat. Jurnal Al-Mauzhah, 1(1).

Nusyirwan. (2020). Kontestasi pendidikan keislaman dan pendidikan umum: persepsi masyarakat tentang sumber kekuatan mobilitas sosial di kabupaten bone. EKSPOSE: Jurnal Penelitian Hukum Dan Pendidikan, 19(1).

Pramudiana, I. D. (2017). Implementasi Kebijakan Pendidikan Inklusif untuk ABK di Surabaya. Jurnal Dimensi Pendidikan Dan Pembelajaran, 5(1).

Ritonga, M. (2020). Learning From Home (LFH) dan Kerinduan yang Mendalam. In Inovasi Pembelajaran Era Covid-19 Pengalaman \& Pengamatan Selama Pandemi Covid19 (pp. 80-83). Cv Markumi.

Ritonga, M., Lahmi, A., Bambang, Ayu, S., Firdaus, Asmaret, D., \& Afdhal, S. (2020). Curriculum Development Strategy Management for Student Mental Health in Covid-19 Pandemic. International Journal of Pharmacentical Research, 12(Spessial Issu 2). https:// doi.org/10.31838/ijpr/2020.SP2.562

Roza, A., \& Rifma. (2020). Perencanaan pembelajaran anak berkebutuhan khusus dalam majamen sekolah inklusif. (JKPD) Jurnal Kajian Pendidikan Dasar, 5(1).

Santoso, D. H., \& Santosa, A. (2020). Evaluasi Pelaksanaan Pembelajaran Online di Tengah Pandemi Covid-19. In D. H. Santoso \& A. Santosa (Eds.), Covid-19 dalam Ragam Tinjauan Perspektif (pp. 69-80). MBridge Press.

Sartika, F., Ritonga, M., \& Rasyid, A. (2020). Implementation of Islamic Religious Education in Madrasah Ibtidaiyah During Covid-19 Pandemic. Khalifa: Journal of Islamic Education, 4(2).

Sitohang, J. (2017). Penerapan Metode Tanya Jawab untuk Meningkatkan Hasil Belajar IPA pada Siswa Kelas Dasar. Suara Guru: Jurnal Ilmu Pendidikan Sosial, Sains, Dan Humaniora Vol., 3(4).

Suparman, Untoro, I. H. T., Suwadi, Prabowo, A., Andriyani, Humanika, E. S., Hairun, Y., \& Ritonga, M. (2020). The Implementation of Community Partnership Program to Improve the Quality of Online Learning during the Covid-19 Pandemic. Universal Journal of Educational Research, 8(11B). https://doi.org/10.13189/ujer.2020.082249

Tambak, S. (2014). Metode Ceramah: Konsep dan Aplikasinya dalam Pembelajaran Pendidikan Agama Islam. Jurnal Tarbiyah, 21(2).

Wati, N. W., \& Wati, N. W. (2018). Peran Guru Pada Siswa Disabilitas di Sekolah Luar Biasa Kota Surabaya. BioKultur, VII(1).

Widiastuti, N. L. G. K., \& Winaya, I. M. A. (2019). Prinsip Khusus dan Jenis Layanan Pendidikan Bagi Anak Tunagrahita. Jurnal Santiaji Pendidikan, 9(2).

Zulfa, U. (2018). Model of Islamic Religion Education 435 Based on Islam Nusantara on College. Nadwa: Jurnal Pendidikan Islam, 12(51). 